Many and various ice surfaces were traversed during the exercise. The initial stage of the route was mainly along the ice foot of the shore of Hudson Bay, where the considerable tides cause frequent overflows yielding lengthy stretches of smooth ice. At river mouths there were air spaces in the ice, which was tide-heaved into a series of smooth undulations.

The lakes in the eastern Arctic were frozen to a depth of six to eight feet. The ice was only partially covered with snow. This snow cover was thinner in the northern part of the route. In the western Arctic, from Coppermine south, there was a uniform cover of soft snow. The ice of Great Bear Lake, the second largest fresh-water lake in the world that freezes completely, was over $5 \mathrm{ft}$. thick. The surface was fairly smooth, but was broken by a number of large pressure ridges running out of sight and characterized by open cracks up to $6 \mathrm{ft}$. wide often masked by drifted snow.

Great Bear River was, and always is, unfrozen where it leaves the lake, but the Mackenzie

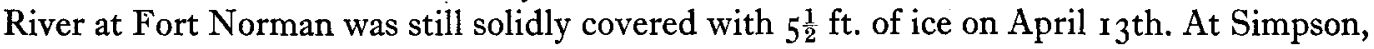
however, the thaw had set in and there was a foot of slush or water above the rotting ice surface. This was characteristic of all the rivers from here south till the Fort Nelson River was reached. Here the last snow had vanished and the river was open and running swiftly.

\title{
MEETING OF THE INTERNATIONAL UNION OF GEODESY AND GEOPHYSICS
}

IN case the note on p. 35 of No. I of this Journal should have misled readers, Dr. J. M. Stagg, General Secretary of the International Assembly of the Union, has written to say that the next General Assembly of the Union, and therefore of the International Association of Hydrology, will be held in Norway in September, 1948. At a meeting of the Executive Committee of the Union at the end of 1945 it seemed possible to hold the General Assembly in 1947. But by the time an Extra-Ordinary Assembly of the Union met in Cambridge in August, 1946, it was clear that post-war difficulties in many countries would still be too great in 1947 to allow a large number of delegates to meet. It was therefore reluctantly decided to postpone the Assembly until September, I 948.

The representative of Norway, the host country, explained that his National Committee hopes to arrange for the Assembly to be held afloat for the first time. The delegates will board a specially chartered ship in Oslo and the meetings of the Union and its component Associations will be held on board as the ship sails up the west coast of Norway.

Mr. Walter D. Lambert, of Washington, D.C., President of the International Association of Geodesy, has also written expressing the hope "as one interested in the success of the Oslo meeting that your organization will be represented there with special reference to the meetings of the Association of Hydrology through the appropriate British National Committee."

The Society is represented on the Hydrology Sub-Committee of the National Committee and members will be informed when, later in the year, plans have taken more definite shape. Members will also be kept informed about the constitution of the British Group of the International Commission on Snow and Glaciers (one of the Commissions of the Association of Hydrology), concerning which the Society is at present in communication with Dr. J. E. Church, President of the Commission.

\section{Papers to be Read before the International Committee on Snow and Glaciers}

The following reporters have been appointed by the Hydrology Sub-committee of the British National Committee for Geodesy and Geophysics :

I. The Origin, Drift and Ablation of Icebergs as Aids in forecasting their Seasonal Appearance : Mr. J. M. Wordie. 
2. The Physical Changes in the Snow conducive to Run-off and particularly to Flooding: Captain W. N. McClean.

3. The Study of the Crystal Structure of a Glacier and its Influence upon Glacier Movement: Mr. G. Seligman.

British contributors of papers on the above subjects should send them to the reporters, either direct or care of the British Glaciological Society, by November I, 1947. At the Washington Meeting in 1939 sixty-one papers and reports were presented to the Commissions of Snow and of Glaciers.

\section{NOTES}

Donations. The Committee wish to give their thanks to the many members who have added donations to their annual subscriptions and also to the Alpine Ski Club, London, for their generous contribution. They desire to place on record how much they appreciate this support.

Honorary Member. Sir George Simpson, K.C.B., C.B., C.B.E., F.R.S., has accepted Honorary Membership of the Society.

Sir George Simpson took part in the British National Antarctic Expedition I9ro-r 3 and was Director of the Meteorological Office from 1920 until 1938 and again during the war.

Scott Polar Research Institute, Cambridge. The Reverend W. L. S. Fleming has been appointed Director on the resignation of Professor F. Debenham, O.B.E.

Dr. J. E. Church writes "I am flying to Manila and up the Yangtze River on my way to India to organize a snow survey system in the Himalaya for the Government of India. On my way I want to get a look at the snow cover on the Yangtze and on my way back I should like to go south from Rio to the San Juan Basin of Argentina in the Andes."

Dr. HeNrI BADER, one of the original research workers at the Weissfluhjoch Snow and Avalanche Research Station, Switzerland, is now working at the Bureau of Mineral Research, Rutgers University, New Brunswick. He has joined the U.S. group of the International Commission of Snow and Glaciers and is a member of the National Research Council Commission on the Ross Ice Shelf.

Dr. S. E. Hollingworth has been appointed to the Yates-Goldsmid Chair of Geology at University College, London.

Die Schweizerische Geomorphologische Gesellschaft. This Society has been formed under the Presidency of Dr. Hans Annaheim, Basle, to co-ordinate geomorphological work throughout Switzerland.

Metric System. At the British Scientific Conference of 1946 it was suggested that the pound and the yard should be precisely related to their metric equivalents. If this is a preliminary step in the adoption of the metric system in the Empire, the least that can be said is that it is long overdue. 